Georgetown University Law Center

Scholarship @ GEORGETOWN LAW

1999

\title{
The Zealous Advocacy of Justice in a Less Than Ideal Legal World
}

Robin West

Georgetown University Law Center, west@law.georgetown.edu

Georgetown Public Law and Legal Theory Research Paper No. 11-79

This paper can be downloaded free of charge from:

https://scholarship.law.georgetown.edu/facpub/662

http://ssrn.com/abstract=1857091

51 Stan. L. Rev. 973 (1999)

This open-access article is brought to you by the Georgetown Law Library. Posted with permission of the author. Follow this and additional works at: https://scholarship.law.georgetown.edu/facpub

Part of the Entertainment, Arts, and Sports Law Commons, Law and Society Commons, Legal Ethics and Professional Responsibility Commons, and the Legal Profession Commons 


\title{
The Zealous Advocacy of Justice in a Less than Ideal Legal World
}

\author{
Robin West*
}

In The Practice of Justice, William Simon addresses a widely recognized dilemma - the moral degradation of the legal profession that seems to be the unpleasant by-product of an adversarial system of resolving disputes-with a bold claim: Lawyers involved in either the representation of private rights or the public interest should be zealous advocates of justice, rather than their clients' interests. If lawyers were to do what this reorientation of their basic identity would dictate-that is, if lawyers were to zealously pursue justice according to law, rather than zealously pursue through all marginally lawful means whatever ends their clients happen to desire-the moral quality of litigation would improve, ${ }^{1}$ as would the reputation of the $b a r,{ }^{2}$ and likewise the justice of the law itself. ${ }^{3}$ But even more telling, for Simon, a system under which lawyers understood the "practice of law" to mean the practice of justice, rather than the zealous but amoral advocacy of clients' ends, would confer meaning and moral purpose in a life presently constructed so as to be dangerously devoid of both. ${ }^{4}$

Lawyers themselves know something is very wrong in the State of Denmark, Simon shows, and have for the better part of at least this century. If we take seriously the "late career," after-dinner speeches and bar association talks given by prominent corporate lawyers, ${ }^{5}$ a grim and telling composite emerges of the trajectory of at least many successful lawyers' lives. Lawyers embark on their careers expecting to be engaged in the pursuit of justice, and by the end of a life spent representing corporate clients, come to realize and lament that they have done much the opposite: They have spent their careers not furthering justice at all, but instead doing parasitic work on behalf of faceless corporate clients whose ends are to maximize profit regardless of

* Professor of Law, Georgetown University Law Center. B.A. 1976, J.D. 1979, University of Maryland; J.S.M. 1982, Stanford Law School.

1. See William H. Snion, The PRActice of Justice: A THEORY of LaWyers' Ethics 1 (1998). Hereinafter, all references to The Practice of Justice will be made by citation to page numbers without additional identification.

2. See pp. 195-215.

3. See pp. 77-108, 138-69.

4. See pp. 109-37.

5. See pp. 1-4. 
social consequences, and who expect their lawyers to manipulate the substance and procedures of law to help them do so. The excessive, relentless, and zealous pursuit of the dubious ends of clients by whatever marginally lawful means are available, rather than a life committed to justice, Simon argues, is felt by the most successful members of the retiring bar as a serious, even profound, moral and existential cost. ${ }^{6}$ And it is experienced by the practicing bar as a numbing, cynical, and exhausting exercise in Darwinian survival where the message of the market is clear: Do anything less, and you will not survive.

Lawyers' professional lives are presently experienced as amoral, Simon argues, because they are amoral, but not for the reason often given by the members of the retiring bar themselves: That ungentlemanly, unprofessional, market-driven, young lawyers have forgotten their manners in pursuit of the legal buck, and have made life nasty and brutish for everyone. ${ }^{7}$ Nor is the lawyer's amorality in any way tied to the nihilistic excrescences of contemporary theoretical understandings of law, as argued by some contemporary scholarship on the subject. ${ }^{8}$ Rather, according to Simon, the amorality of lawyering stems directly from the stated ideals and aspirations of the profession itself. 9 The ideal of lawyering espoused by the profession, and memorialized by the various codes of ethics that govern it, strips the lawyer of responsibility for the moral quality of not only his clients' ends but also of his own actions taken on his clients' behalf-and all on the dubious bet that by so doing, the system, in some mechanistic and formalistic manner, will almost miraculously crank out justice as the outcome.

The bet at the center of this "dominant view," good one-justice is not going to be the miraculous product of a system in which none of the actors are required to pursue it. The lawyer knows this full well, furthermore, and as a consequence both the lawyer and society bear a loss-society by being saddled with a profession that permits and seemingly requires that individual lawyers aggressively pursue injustice, and the lawyer by being saddled with a life-long and deeply hurtful existential alienation from his work. To address the harm, we need, essentially, to reorient the profession by redefining its core moral identity. The lawyer should indeed zealously advocate, but he should zealously advocate for justice, not for the satisfaction of the preferences of his particular clientele.

Simon is not alone in this view, and he is not the first to address the apparent amorality of lawyering with an argument that what the bar must do is drastically restructure the lawyer's adversarial role, rather than explain it to a

6. See pp. 109-37.

7. See pp. 1-4.

8. See pp. 2-4.

9. See pp. 1-25, 195-215:

10. P. 7 
doubtful public who obstinately fail to appreciate its social value. In fact, an entire school of criticism of adversarial ethics-a criticism which Simon, following convention, calls the "role morality" or sometimes the "personal morality" critique ${ }^{11}$ - has, over the last twenty years or so, sown seeds of doubt regarding the dominant view. "Role morality" critics fault the traditional adversarial model for its tendency to limit the moral obligation of the lawyer to his client, and to minimize to almost nothing the ordinary moral obligations that the lawyer, but for his professional role, would owe to others. ${ }^{12}$

The result of this role-defined morality, according to the "role morality" critic, is that the lawyer is correctly perceived by the lay public as a less than ordinarily moral individual: The lawyer, because of his professional adversarial role, need not act in a way that gives equal regard to the moral worth of all. He need not act justly, or honestly, or honorably. He need not, and routinely does not, for example, seek to present a truthful understanding of past events to the world. He can seek to destroy the reputation of those he knows to be upright individuals. He can seek to destroy the credibility of witnesses he believes to be truthful. He can seek to further his clients' ends so long as they are lawful, although he believes those ends to be socially harmful. $\mathrm{He}$ can refuse to alleviate personal suffering of others when he could easily do so simply because his client, for reasons whimsical or worse, refuses to permit it. Most of the ethical dilemmas of lawyering, according to the "role morality" critique, can be attributed to the peculiar diminution of ordinary moral obligation inherent in the lawyer's professional role. And, in most of these situations, the lawyer's professional role, according to the "role morality" critics, is indeed drawn too narrowly. There would be little to lose in terms of justifiable zealous advocacy and much to gain in terms of public trust, social welfare, and professional reputation, were the lawyer's role redrawn to bring into closer alignment "ordinary morality" and "professional morality," and thereby to include rather than exclude some of these otherwise obligatory ordinary moral duties.

Simon's book can perhaps best be read as an internal and friendly critique of this "role morality" argument, and then an attempt to rehabilitate it by resting it on a sounder foundation. It is important to stress, however, before examining the differences between them, how much territory is shared. Bill Simon shares with the "role morality" critics a strong revulsion for the excesses of zealous advocacy, and reaches many of the same conclusions

11. See pp. 15-18. See generally DAVID LUBAN, LAWYERS AND JUSTICE: AN ETHICAL STUDY (1988); THOMAS L. SHAFFER \& ROBERT F. COCHRAN, JR., LAWYERS, CLIENTS, AND MORAL RESPONSIBILITY (1994).

12. See generally, LUBAN, supra note 11; Heidi Li Feldman, Codes and Virtues: Can Good Lawyers Be Good Ethical Deliberators?, 69 S. CAL. L. REV. 885 (1996); Richard Wasserstrom, Lawyers as Professionals: Some Moral Issues, 5 HUMAN RTS. 1 (1975). 
regarding particular cases and common dilemmas. Like the "role morality" critics, for example, Simon urges that lawyers should abstain from only marginally legal procedural tactics that promote their clients' ends through gaming the system rather than engaging its substantive content. ${ }^{13}$ Like them, he argues that lawyers should refrain from making outrageous or worse legal arguments that, while arguably true to the letter, clearly frustrate the intent and meaning of the law. ${ }^{14}$ Like them, he argues that lawyers should understand their duties as "officers of the court" to impose obligations that extend to non-parties and to the public as well as to the client. ${ }^{15}$ Like them, Simon also argues that lawyers should abstain from using even lawful means on behalf of their clients' ends if those means and ends cause substantial injustice to others. ${ }^{16}$ Further, like the "role morality" critics, and inspired by Brandeis, he argues that lawyers should understand their role as including, not excluding, an obligation to critically challenge their clients' ends when those ends are technically lawful but nevertheless unjust, at odds with legal obligation broadly understood, or evasive of civic responsibility. ${ }^{17}$ Finally, like them, Simon argues that lawyers should understand the work of bringing the law into an ever-closer convergence with the requirements of justice, whether through litigation or law reform, as absolutely central to their legal identity. ${ }^{18}$

For anyone who has followed the development of the "role morality" critique, the harms that Simon identifies and connects with the lawyer's professional role, and the morally outrageous examples he uses to illustrate those harms, are not particularly surprising or new. The argument that Simon makes for his reorientation of the basic ethical obligation of the legal profession, however, is quite new, and more than a little surprising. It is strikingly different from the argument put forward by the "role morality" critics. What lawyers have to do to zealously practice justice, Simon argues, is to be in essence better lawyers. ${ }^{19}$ The justice lawyers are or should be morally bound to pursue, Simon reassures us repeatedly, is nothing more and nothing less than the law itself; or as he sometimes puts it, the "legal merits." 20 Lawyers should promote justice, and what justice requires, in any case, is what the law requires. Rather than blindly aim to promote their clients' interests, lawyers in the practice of justice need only do what they are trained to do: seek to vindicate the legally-compelled result.

13. See pp. 4-18, 163-69.
14. See pp. 164-66.
15. See pp. 163-64.
16. See pp. 160-69.
17. See pp. 126-35.
18. See pp. 138-69.
19. See pp. 109-37.
20. See pp. 9-11, 77-108. 
How can it possibly be that what "justice" requires in a legal context is nothing different than what "the law" requires? What sense can be made of the equation of justice with law? Simon borrows the argument for this equation, which is central to the heart of his book, in toto from Ronald Dworkin. ${ }^{21}$ Following Dworkin, Simon insists that the substance of any body of law is defined, constituted, and constrained by moral principles of justice. ${ }^{22}$ In Anglo-American law at least, and maybe in any mature legal system, it is just not possible to accurately state a legal claim or argument without incorporating the principles of justice that define its limits and animate its core. ${ }^{23}$ Non-positivist moral principles such as "no person should profit from his own wrong," or "manufacturers should not fleece the unsuspecting public through form contracts that strip them of their rights to recourse in the event of negligently caused personal injury," for example, are not willy-nilly superimposed when a judge feels like it upon a body of otherwise positivistically pure and straightforward and amoral estate or contract laws. Rather, such principles of justice-potentially infinite in number and mind boggling in their complexity-are central to the law itself. The law of contracts, for example, includes and is partly defined by the moral principle that no one should profit from unconscionable contracts. The law of trusts and estates includes and is partly defined by the moral principle that no one should inherit under a will written by a testator whose death he has feloniously caused, and so on.

Still following Dworkin, Simon goes on to argue that lawyers' behavior and arguments illustrate the interdependency of law and notions of justice. A good or even competent lawyer's restatement of "The Law" on any topic whatsoever, whether in a brief or in an opinion letter, will quite routinely seek to glean from the relevant legal materials not just positivist mandates or clues to enhance his predictive prowess, but rather, the moral principles that define and constitute that body of law. ${ }^{24}$ The lawyer, so armed with those principles, is able to state the law more completely. Only then can he hope to apply "The Law" to the facts on the table accordingly. Again, it is worth emphasizing, that this is the way that lawyers already think about law according to both Simon and Dworkin. The substance of law itself simply rests on and incorporates the demands of justice. The arguments and the form of arguments that lawyers make when arguing about the content of virtually any body of law clearly reveal their rock-bottom nonpositivist moral assumptions. Any professionally credible restatement of any body of law relies

21. See generally RONALD DWORKIN, TAKING RightS SERIOUSLY (1977) (arguing that a legal system must vindicate people's "natural rights").

22. See pp. 37-43, 82-108.

23. See pp. 37-43, 82-108; see also DWORKN, supra note 21, at 206-22 (arguing that law must take into account moral principles).

24. See pp. $37-40$. 
heavily and inextricably on highly contextualized judgments regarding precisely the content and contours of these norms of justice.

It is only when faced with questions of legal ethics, Simon goes on, that lawyers do an inexplicable and unjustifiable about-face, and begin to deny what they otherwise clearly know to be the case: the interdependence of law and norms of justice. ${ }^{25}$ A lawyer's understanding of "law," when faced with the task of specifying the ethical limits of zealous advocacy, is suddenly stripped from his understanding of "what justice requires," and his felt responsibility to "get the law right," is suddenly drained of any responsibility to grapple with the meaning of justice.

The result of this disassociation is a sort of professional moral hypocrisy, or even schizophrenia. The lawyer writing the op-ed piece knows that contract law incorporates and depends upon moral principles. When faced with the client who wants out of a contractual obligation, however, that same lawyer suddenly forgets his subtle and principled understanding of contract law, and interprets the law of contract and the statute of frauds as though they had positivistic content only. Similarly, principles that in nonadversarial contexts the lawyer clearly knows limit legitimate contractual nonperformance based on the passage of time, disappear from view in the adversarial context. Likewise, when faced with the client who wants a limitation of liability clause, the lawyer reads the law narrowly so as to exclude principles that in other contexts he recognizes limit, on moral grounds of justice or economic grounds of efficiency, the hand of the stronger party in dictating terms to the weaker. The governing norm in all of these cases, when the lawyer is performing as an advocate, is no longer the moral principle that otherwise defines and constrains law. Rather, it is the risk of exposure to adverse adjudicated decisions. The "law" for the traditional zealous advocate becomes defined in terms of the chances the client will suffer adverse consequences in the system, rather than defined in terms of the moral principles that the lawyer knows give the law its sense and moral substance.

A good lawyer, Simon argues, should not have one understanding-the moral substantivist one-for his op-ed writing, and another-the positivist or Holmesian bad man's-for his brief writing. The law of contract includes moral principles that limit the waivers that can legitimately be stuck in a form contract, and they limit them beyond the scope of those which are most likely to be found and struck by a court. Good lawyers know that the law of trusts and estates limits the power of testatees to inherit from people they have murdered, and this limit extends beyond the scope of those likely to be so adjudicated. A good lawyer should not hypocritically and selectively embrace positivist conceptions of the "The Law" that render the law amoral or absurd, when it is in their clients' interests to have the law so read. Good

25. See pp. 1-52. 
lawyers know in the abstract that our legal rights and duties, best understood, cannot be derived positivistically from predictions of state commands narrowly construed; to do so would do violence to the task of sensibly articulating even banal or straightforward legal obligations.

Those same good lawyers should not, then, embrace this super-positivist posture when advising or advocating on behalf of clients. Such a posture does little but morally crib their practice and distort and mangle the law. When advising and advocating for their clients they should act on whatever understanding of law is the best and most moral. They should infuse their practice, in a nutshell, and not just their theoretical musings, with a substantive understanding of the "The Law" that defines their clients' rights and obligations as incorporating general moral principles of justice. ${ }^{26}$

If Simon is correct in prescribing what lawyers should do, then the problem with the traditional model of zealous advocacy is not that it shortchanges our ordinary moral obligations in favor of a legally constrained role morality, as the "role morality" critics argue. The problem is essentially that the traditional model shortchanges, and misconstrues, the nature of law. Law-at its core-incorporates the very constraints of justice which the traditional adversarial model forces the lawyer to disown. If lawyers simply incorporated in their practice of law the justice which they otherwise acknowledge to be a central defining part of substantive law, many of the traditional ethical dilemmas would for the most part disappear, or at least would be cast in a very new light.

In this context, the lawyer would advise the client not to plead the statute of limitations where it would be unjust to do so, regardless of whether or not a future court or state decision-maker would ever so decide. He would do so for the straightforward and lawyerly reason that the law of contracts, which it is his duty to accurately convey, incorporates such a limit. Likewise, the lawyer would advise the client who wants the liability waiver in a form contract that the law won't allow it. The contractor who seeks to avoid performance on the grounds that it is cheaper to breach than to perform, given the high costs to the nonbreacher of enforcing the contract, would be correctly advised that the law does not permit this sort of strategic behavior. Furthermore the client who wants the lawyer to make dubious arguments, game the system, or engage in acts of substantive hypocrisy, would be routinely and correctly advised that such actions are precluded by law: Law incorporates and rests on norms of justice that bar unethical conduct. Clients who seek the services of lawyers to promote their socially dubious or harmful ends, likewise, can minimally expect an earful from their hired hand, and possibly face the prospect of not finding any lawyer anywhere willing to assist them. Law incorporates and rests on norms of justice, and justice precludes the

26. See pp. 138-69. 
satisfaction of certain ends. It follows that the lawyer as lawyer-not lawyer as moralist-need feel no obligation to further unsavory or morally problematic ends, make unjust legal arguments, use tactics that further rather than frustrate known ends of the law, or engage in acts himself or acquiesce in those of his client that bring about manifest injustice. He may indeed have an obligation to resist them.

This argument has a number of virtues. First of all, strictly jurisprudentially, were Simon to succeed in his proposed re-orientation of the lawyer's role, it would strengthen considerably Ronald Dworkin's theoretical challenge to positivism. That challenge only works if it is the case that lawyers really do talk about law in a way that reveals its synthetic incorporation of norms of justice. To the extent it is client interest rather than the most just or moral interpretation that drives a lawyer's understanding of law, the Dworkinian case is weakened. So if Simon could effectuate the change in professional norms and culture which he advocates, Dworkin's grand synthesis of legal prescription and moral principle would be somewhat closer to the real world.

Second, in terms of the profession, it would surely gain in both reputation and nobility if lawyers incorporated into their norms of practice whatever norms of justice could fairly be attributed to their best understanding of the law itself. Most importantly, the substance of law, and hence the workings of our world, might become more just if we set up professional norms to encourage or promote private compliance with justice through the advice of privately retained attorneys. Our law, as Simon says, when best read by lawyers, really is constrained, informed, and constituted by justice-not by litigators' best predictions of the outcomes of unlikely litigation brought on behalf of Holmesian bad men fully informed of the low likelihood of their getting caught. If lawyers acted on those morally best readings when advising clients, rather than on their best predictions, our law would presumably improve.

To put the point more concretely, if corporations were advised on a norm of contract law, for example, that meaningfully incorporated a justice-based limit of unconscionability on unread contract terms in form contractsrather than a norm informed by the realist insight that the law of contracts is nothing more grand than what a court might in the future pronounce, particularly given the low chance of litigation or enforcement-there would be fewer unconscionable terms out there structuring the ubiquitous contractual world. The same would be true of virtually every body of law. Our criminal justice system might not be the mess it presently is, if an obligation to justice directed prosecutors, rather than the need to compile an impressive conviction rate. To take one example not explored in Simon's book, corporate and individual compliance with the arcane intricacies of tax law would surely be higher if tax lawyers acted on their understanding of the true meaning of that 
body of law, rather than their understanding of what their clients demand to be told, namely, their minimum tax obligation informed by the very slight risk of an audit. Tax attorneys might be much more likely to act on a morally-informed understanding of the law, furthermore, if they construed their professional obligations as requiring it. Currently, they do not perceive their obligations in this manner, and the tax bar and a depleted treasury bear the brunt of the consequences. Existentially and personally, the reorientation for all lawyers might have much to commend it. Like the doctor in compliance with his oath to do no harm, the lawyer in compliance with his professional oath to do justice, or (at least) to not promote injustice, might sleep better at night, and perhaps glean greater satisfaction from his career as well.

It might also be the case, as Simon clearly believes, that the bar would be more likely to achieve such goals through his proposed substantive reorientation of the lawyer's role than through various mechanisms propounded by the "role morality" critics. ${ }^{27}$ Simon's proposal is simply more radical than the reorientation proposed by the "role morality" critics, in the ordinary use of that term: It cuts to the heart of the lawyer's role, rather than focusing on the excesses. At the same time, unlike theirs, Simon's proposal is deeply conservative: It views ethical excesses as a repudiation or departure from true law and true advocacy, as best understood, and views the work of the legal ethicist to be the task of capturing in practice what the ideal has always proscribed in theory. For both reasons, Simon's account, arguably, is more respectful of the profession as currently configured, even while it cuts deeper.

Simon's proposal calls lawyers to their best self-conception, by calling on them to be true in practice to their moral understandings of the substance of "The Law," the intricacies of which, after all, constitute the heart of the lawyer's claim to professional expertise. It demands, in essence, a reorientation of the lawyer's professional role toward justice, but does not demand incorporation of extra- or non-legal moral norms. Rather, it demands a reorientation of the lawyer's professional role toward justice so as to be truer to the law itself, and truer to the lawyer's best understanding of it. It argues, to state the contrast a little differently, for a revitalization or even an enlargement of the lawyer's distinctive professional role so that the lawyer pays his due to the justice already inscribed in our law, rather than a diminution of the lawyer's distinctive professional role to better align it with the dictates (and pieties) of conventional morality. All of these, I think, should count as strengths of Simon's position. The reorientation for which he argues, were the profession to embrace it, would incorporate into the norms of practice a moral view of law and justice that is itself perhaps the best and most moral 
possible interpretation of our current legal practices. Simon wants practice to become more just by putting it in quest of itself, in a way not at all dissimilar to Lon Fuller's search, some fifty years ago, for a path by which law could do likewise. ${ }^{28}$

Simon's proposal does, however, have problems. One is descriptive, one normative, and one aspirational. First, the descriptive problem. Simon's argument is essentially the following: (1) Lawyers should pursue justice; (2) What justice requires, in turn, is what the "legal merits" of the case would dictate, in a world without static - a world without the gameplaying, loopholing, disingenuous and hypocritical arguments, delaying tactics, and Holmesian bad men, that presently populate and contaminate adversarial legal process. This argument demands the conclusion that lawyers should zealously advocate the resolution of a case as dictated by its underlying legal merits. But what sustains the leap of faith represented by premise (2)? In what possible sense can it be true that "justice" simply is whatever the legal merits dictate?

The evidence for the second premise, as briefly mentioned above, comes from the legal and judicial practices of lawyers and judges, presumably when making legal arguments in nonadversarial settings. When debating the meaning of a legal norm, lawyers and judges reveal in their arguments the deep interdependence of legal and moral norms. Simon points to a few cases that he thinks amply illustrate the point. In a famous case now almost one hundred years old, a state court found a will to be constrained by the moral principle that a "man should not profit from his own wrong," and accordingly struck a bequest to the testator's murderer, even without clearly applicable precedent allowing it to do so. ${ }^{29}$ In a similar vein, the Supreme Court in Green v. Book Laundry Machine Co. ${ }^{30}$ unanimously interpreted a provision in a statute that explicitly refers to criminal "defendants" in such a way that it also covers civil plaintiffs, presumably on the moral grounds that the same set of reasons that dictate the necessity of the statute for defendants in criminal cases is equally applicable to plaintiffs in civil cases. ${ }^{31}$ On the basis of Green, and a few cases like it, Simon boldly concludes (as did Ronald Dworkin, on even scantier evidence thirty years ago) that legal and judicial practice reveal the deep interdependence of justice and law. ${ }^{32}$ Therefore, Simon sums up, these practices reveal that a lawyer committed to the pursuit

28. Lon Fuller stressed that it was important to regard law as an instrument for society moving toward certain goals, and to ask questions about which solutions best advanced these goals. Fuller tried to settle questions about the legal process instrumentally. See DWORKIN, supra note 21, at 4.

29. See pp. 37-42; see also DWORKIN, supra note 21, at 23.

30. 490 U.S. 504 (1989).

31. See p. 38 (citing Green v. Book Laundry Mach. Co., 490 U.S. 504 (1989)).

32. See p. 39; see also DWORKN, supra note 21, at 14-45. 
of justice need not refer to extra-legal norms, indeed he must not do so. The lawyer committed to the pursuit of justice need consult only the underlying legal merits. Lawyers ought to engage in the practice of justice; and justice requires, essentially, what the law dictates. Our present practices reveal as much.

The descriptive problem thus arises: Simon's argument rests on the quasi-empirical claim that the equation of justice with law is born out by the structure of contemporary lawyers' arguments. Lawyers seemingly know, and their legal arguments reveal that they know, for example, that contract law best understood is constrained by norms of unconscionability, or that estate law includes norms against profiting from one's own wrong. But it is not clear at all either that lawyers agree with such conclusions or talk as though they do. If we take seriously Simon's own dire descriptions of legal practice, we have good reason to think they do not. Who are the lawyers who agree with Simon and talk as he says they do? Who are the lawyers who make arguments about the substance of the law routinely revealing such a lucid association between law and justice? Most lawyers, when following the traditional model of advocacy, of course, do not talk this way, but this is the status quo which Simon seeks to change. The problem is that he seeks to change that status quo by recourse to a view of law that is itself informed by an idealized view of actual legal practice-one that constructs ideal legal arguments unpolluted by the errant adversarial ethic under scrutiny. For the argument to work, though, there has to be some nonadversarial legal arena in which lawyers make arguments that reveal their deep understanding of the interdependence of legal and moral norms. Is there any such arena? Are there any such lawyers?

There are, of course, many lawyers who never talk in the Simonian or Dworkinian way, even in their most nonadversarial, contemplative, detached, authorial modes. Lawyers influenced by a public choice model of legislation, for example, might be disinclined to accept the Dworkinian or Simonian picture of how we ought to interpret statutes. Law-and-economics trained or influenced lawyers might be expected to resist mightily the incorporation of justice into any interpretation, lawyerly or otherwise, of contractual obligations, and they are lawyers too. More broadly, though, the recourse to some deep, albeit suppressed, knowledge about the moral foundation of law among lawyers themselves might fail by its own terms. It might be true that some lawyers of a particular historical moment talked in a way that revealed their appreciation of the interdependence of legal and moral norms, at least when their conversations were not polluted by traditional adversarialism. It seems unlikely, however, that lawyers have always talked in such a way, and doubtful they do so now. Simon often speaks as though his core claim that justice is law-that justice equates with a deep interpretation of extant legal norms (although one might, of course, have to dig down very deep to get past the 
muck)-has become accepted, conventional wisdom in the profession. But that is clearly an overstatement. Very likely, there may be no legal philosopher or legal scholar other than Dworkin himself who believes this argument in its most extreme form-namely, that virtually every legal question has one morally principled right answer, fully determined by the matrix of moral and legal principles that govern it. Students, in my experience, do not generally find compelling, or often, even coherent, Dworkinian jurisprudential descriptions of lawyers' arguments. To the contrary, many students, maybe most, find the moral objectivity Dworkin ascribes to the standard legal argument, as well as its radical detachment from history, utterly foreign. Whether they are right or wrong to be so skeptical is not the point. My point here is only that both Dworkin and Simon might be mistaken to rely on "the way lawyers talk" to substantiate their claim that law has the moral content that they claim it has. If lawyers do not talk in a way that reveals a deeprooted association between law and justice, or do not talk that way anymore, or are moving toward a point in time when they will not talk that way ever, then the argument is in trouble. The difficulty, furthermore, is much more acute for Simon's claim than for Dworkin's. Simon's argument, after all, unlike Dworkin's, begins with a devastating portrayal of the extent to which at least litigating lawyers do not talk that way now, at all.

The second problem with Simon's proposal is moral. Do we really want lawyers, as professionals, to identify the demands of justice with even an idealized, deep-digging interpretation of extant law? Is our law really that good? What happens if it falls from grace? What happens if our deepest, most fundamental, most basic law, when best read in its most moral light, takes a disastrously bad, immoral, evil turn and becomes utterly, inarguably unjust? What if it already has? Who will notice, and who will not? Will a legal profession first trained, and then required, to equate justice with the best possible interpretation of extant law not be less inclined than their positivist brethren to recognize wide-scale, state-sanctioned evil?

Maybe it is morally better, as Simon clearly believes, for lawyers who represent corporate interests to strive for justice as defined by law, rather than for legal results as defined by corporate client interests. But surely we do not want to universalize such a claim. After all, even if it is acceptable that corporate lawyers constrain their clients' ends with their reading of the "legal merits" so as to promote justice, this might be true precisely because the particular substantive law that governs those transactions requires more justice than those particular corporate clients are predisposed to dispense. It does not follow that all lawyers who should strive for justice should identify justice with extant law. Some law, after all, even when read in the very best moral light imaginable, is just plain flatly unjust. If we identify justice with extant law, and train lawyers to do likewise, we run the serious risk of foregoing the critical capacity to identify law that is evil. If we equate law with 
justice, its hard to know how we are ever going to even identify, much less rectify, reform, resist, or overthrow, patently unjust laws. And its hard to know where the lawyer will be in such a struggle.

There is, to be sure, a very real potential for moral progress in the nonpositivist, or, as Simon is inclined to put it, the "substantivist" path of the law that Simon has uncovered for lawyers. Simon provides two telling examples. After much study, Frederick Douglass, along with a number of other antiabolitionist lawyers, eventually came to the conclusion that precisely because slavery was fundamentally unjust, it was therefore unconstitutional, and hence illegal..$^{33}$ It followed, then, that no one, surely no abolitionist judge, was required to apply the morally evil body of "law" that governed the slavery. That body of law, far from being law, represented nothing but illegitimate state action. Similarly, during the civil rights era, as Simon shows, many (although not all) of the prominent leaders of the movement insisted on the legality of the protestors' actions, and the illegality of the segregationist regime, and they did so essentially on Simonian and Dworkinian grounds. ${ }^{34}$ They argued that justice is a necessary condition of law, and that the injustice of these state pronouncements rendered them unlawful. ${ }^{35}$

Now, if Douglass' argument had been successful we might have avoided a war. The recourse to natural law in the civil rights struggle (along with the use of religious metaphor as well) no doubt helped the civil rights movement keep its collective eye on the prize. Given a substantivist rather than positivist understanding of law, the disobedient demonstrator could be portrayed, and could understand himself, as the true citizen standing faithful to "The Law," and the venal statutes and ordinances being broken as state sanctioned crimes. Both the unsuccessful abolitionist argument and the stunningly successful civil rights claim are striking examples of the potential for moral progress promised by Dworkinian understandings of law and morality. If lawyers were professionally obligated to read, interpret, and apply the law in its morally best light, these successes might be institutionalized, and normalized. The constant moral improvement of the law might become simply the order of the day.

But there is peril in this romantic conception of the invariable goodness of law, and the invariable illegality of injustice, and it is a peril that Simon, I think, just does not see, perhaps in part because he is blinded by the light of substantivism's promise. If lawyers are professionally trained to equate justice with law, they may be more inclined than they would be otherwise to aim for justice in their practice, but they might also be much less inclined than they would be otherwise to recognize real state-sanctioned evil for what

33. See pp. 101-02.

34. See p. 102.

35. See p. 102. 
it is. Douglass did indeed, anticipating Simon and Dworkin, reason that since law is constrained by justice, then the injustice of slavery implies its illegality as well. But what neither Simon, nor for that matter Dworkin, ever fully comes to grips with is that it would be equally plausible for the slaveowner to reason from the substantivist's anti-positivist equation of law with justice, that if law is justice, and slavery is permitted by law, well then, slavery must therefore be just. Similarly, if justice is law, and law is justice, then the segregation ordinance-since it is clearly a law-must therefore be just as well.

These latter arguments-if it is law it must be just, rather than if it is unjust it cannot be law-represent the potential for moral disaster latent in the substantivist's equation of law with justice. It is true, that the substantivist lawyers might be inclined to doubt the legality of unjust state action as Simon hopes. But it is also possible that they might be inclined instead to invest in morally dubious law a justice it utterly lacks. It is this worrymuch more than the "slide to anarchy" that Simon concedes is a danger of substantivism - that has prompted positivists for two hundred years to worry that if lawyers embrace substantivism we risk losing our critical, discriminating, dissenting voices. Substantivism, should we ever be faced with widespread state-sponsored evil, might inspire lawyers to moral action. But it might not. It might do little more than provide a veneer of legitimacy to the moral posturing of lawyer-apologists-precisely the evil Simon seeks to avoid.

Which outcome is more likely should the bar embrace substantivism-its moral promise or its moral peril? A lawyer trained in the substantivist manner to equate law with justice might well insist that unjust state action is therefore not law, might inform his practices accordingly, and might prompt quite meaningful moral change. But surely it is at least as likely, and, I would submit, perhaps a great deal more likely, given the predispositions of the lawyering class, that the lawyer will take from his substantivist education a rather different message: He will happily see justice, wherever he sees state action. Lawyers do, after all, tend to value order highly, and tend to value continuity with the past as well. The substantivist equation of law with justice might allow the lawyer to stick with law past the point where he should, and do so with a higher level of moral comfort. Of course, this is admittedly rank armchair speculation-the bottom line is that there is no good way to tell. Whether the potential for moral progress inherent in the substantivist's equation-the potential, that is, that the law-justice equation will improve the morality of law and its practice-outweighs the risk of moral catastrophe - the profession-wide loss of critical perspective followed by an acquiescence of the legal profession in state evil-is a hard question, and there is no clear way to resolve it. Chances are, that resolution will depend upon historically contingent factors. Certainly, though, no amount of 
philosophical argument on either side of the positivism/substantive debate will close it.

The aspirational problem, finally, is this: It is not at all clear that the reorientation for which Simon argues, even if desirable, would have the redemptive effects on the profession for which Simon hopes. If corporate lawyers are existentially and morally dissatisfied at the ends of their careers, it might be because the law itself-the very legal merits Simon goes to such lengths to celebrate-is substantively unjust. Those lawyers who give those bar association dinners might be spending more of their time than Simon is willing to credit doing exactly what he prescribes, and yet they still have that sinking feeling at the end of the day that they have systematically thwarted, rather than furthered, justice. If so, the cause for their unease may be that the law that they have been quite faithfully interpreting - not mangling-causes substantial injustice and brings about disproportionate misery on those least able to bear it. If the lawyer has been complicit in that process, he might well come to regret it. The level of existential and moral regret that Simon describes might be more plausibly attributed to the injustice of the legal merits the lawyer is faithfully advocating, rather than the lawyer's occasional, or even frequent, ethical lapse.

\section{CONCLUSION: THE PATH NOT TAKEN}

Let me end with a rhetorical question: Why does Simon, after idealistically and even audaciously insisting that lawyers ought to engage in the "practice of justice" and advocate just results rather than their clients' ends, then equate, with surprisingly little discussion, justice with "the legal merits"? I suspect the answer has to do with his perception that there is a dearth of meaningful alternatives. If we do not equate "justice" with "law," Simon might worry, then the lawyer committed to "justice" will be thrown back on the vagaries and uncertainties of his own subjective, even "personal" (horror of all horrors) moral code. If justice is not law-and hence objective, shared, and at any rate a moral improvement over the rapacious interests of a corporate clientele - then the "justice" that the justice-practicing lawyer will practice will simply be one of a catalogue of "personal moral values." It could mean anything and everything. We would then be thrown back into the world of the "role morality" critics. The lawyer's professional role has to be circumscribed, but circumscribed with nothing more substantial than his own personal, private, subjective, moral beliefs. This result is simply not tolerable. It is worse than the disease it sets out to cure.

It is probably worth worrying about why we have, or at least why Bill Simon has, such a dim view of the personal morality of lawyers and nonlawyers alike. By way of conclusion, though, I want to ask a more limited, and I think more answerable, question: Why do we have, or at least why 
does Bill Simon seemingly have, such a dim view of the lawyer's possible understanding of the virtue of justice? Why not say, as Simon says, that lawyers ought to pursue justice, and then either tell us what the justice they ought to pursue requires, or leave it to the practicing lawyer himself to so determine? Legal justice, after all, does not mean just any old thing we want it to mean. The legal justice that courts are supposed to dispense, and that lawyers who practice justice could be required to promote, could, presumably, be given some concrete content. Why not, then, redefine the lawyer's role as the practice of justice, rather than client's ends, as Simon wants to do, and then define the justice he is required to practice by reference to the requirements of justice, rather than by reference to law? Legal justice would, presumably, much of the time, require the lawyer to argue the legal merits, just as Simon argues. But it would not do so by definition, and it certainly would not do so all the time. Whether or not it so required would in turn require precisely the contextual judgment Simon in other parts of this book demands. What the lawyer categorically must do is pursue justice. But whether that does or does not require fidelity to, or zealous advocacy of, the "legal merits" depends on the justice of those merits, and the justice of the legal merits cannot be decided in a circular fashion by reference to the merits themselves. Why is this not a viable option? Why is it not even discussed in Simon's book?

One reason might be that we really do not have at our disposal a credible, or even coherent, understanding of the requirements of legal justice, and one reason for that is surely that both the law schools and the bar, at least in this century, have simply neglected the task of producing one. Since Holmes' dismissive allegation that a lawyer who resorts to arguments based on "justice" is merely revealing either that he has no credible legal argument, or worse his legal ignorance, we have all been seemingly loathe to address the topic. Holmes chided us out of it. ${ }^{36}$ As a consequence, as a profession, lawyers not only lack a coherent or credible idea of what legal justice might require of advocates, of judges, and of the law itself, we do not even have a family of competing ideas. We have no sustained body of scholarship that examines the concept. Nor do we teach a concept of justice. We profess in neither our jurisprudence nor our legal ethics courses, anything about the meaning of legal justice, as it has been understood in either law or in the humanities. We never ask our students in any systematic way what they think justice is or requires, nor do we ever feel the obligation to share with them our own thoughts. So, when the appealing suggestion that lawyers should pursue justice is put forward, there are seemingly only two alternatives for defining the justice those lawyers ought pursue: Justice might be defined by reference to an idealized conception of extant law, or justice might be de-

36. See Letter from O.W. Holmes to Dr. Wu, in JUSTICE OLIVER WENDELl HolMES: HiS BOOK NOTICES AND UNCOLlECTED LETTERS AND PAPERS 201 (Harty C. Shriver ed., 1936). 
fined by the personal predilection of those individuals required to dispense it. It is probably no more than quirks of personality that determine who thinks which alternative is worse.

Surely, it does not have to be this way. Lawyers, judges, law students, and law professors could take up the distinctly jurisprudential project of understanding the demands and content of legal justice - the justice, that is, that courts are required to dispense and lawyers encouraged to practice. It may be that were we to do so we would discover that people in law and lawrelated professions do have a set of consistent, defensible, coherent, and even admirable beliefs - some grounded in intuition, some in remembrance, some in experience, and some, perhaps, in learnings borrowed from the humanities-of what "legal justice" requires. It may be that those beliefs, once articulated, argued over, debated, qualified, and sifted through could constitute something like "a concept of legal justice" that could, in turn, inform our legal practices, both substantive and procedural. If so, then the "legal justice" which we might plausibly say that lawyers ought to practice need be neither identified with extant law nor with personal whimsy. Instead, it might be identified with the demands of the virtue itself, as we have come to understand it. Were such a time to come to pass, then the invitation to engage in the practice of justice would imply neither the risk of undue valorization of the law, nor the risk posed by the unleashing of anarchic and undisciplined personal predilections, masquerading as "personal moralities," of thousands of newly empowered lawyers. Maybe it is absurdly optimistic to think that such an endeavor - the endeavor, that is, of collectively providing an objective definition of the core demands of legal justice-would be a meaningful one, particularly in a postmodern and skeptical era. But it is a project which, for a host of reasons, has not been tried, at least not in this place and in this century. It might be time to try it. 